\title{
Dampak pandemi COVID-19 terhadap pendidikan tinggi di Kota Malang
}

\author{
Eka Ramadanti, Imam Mukhlis*, Sugeng Hadi Utomo \\ Universitas Negeri Malang, Jl. Semarang No. 5 Malang, Jawa Timur, Indonesia \\ *Penulis korespondensi, Surel: imam.mukhlis.fe@um.ac.id
}

Paper received: 3-3-2021; revised: 24-3-2021; accepted: 28-3-2021

\begin{abstract}
Abstrak
Dengan adanya pandemik Covid-19 yang melanda dunia berdampak pada semua sektor bukan hanya sektor ekonomi saja tetapi sektor pendidikan juga terdampak. Proses belajar mengajar yang biasanya dilakukan langsung di kelas akibatnya harus dilakukan melalui daring/online untuk menekan laju penyebaran Covid-19. Oleh karena itu penelitian ini bertujuan untuk melihat dampak yang terjadi akibat Covid-19 terhadap sektor pendidikan tepatnya perguruan tinggi di Kota Malang dengan menggunakan metode eksploratif dan analysis data secara deskriptif. Hasil dari penelitian ini menunjukkan bahwa dalam model pembelajaran daring memiliki beberapa kendala bagi mahasiswa seperti mengeluarkan tambahan biaya untuk membeli paket data, penyampaian, dan penangkapan materi dalam model pembelajaran daring yang kurang maksimal sehingga hal ini memberikan dampak terhadap nilai Indeks Penilaian (IP).
\end{abstract}

Kata kunci: covid-19; pendidikan; kuliah online; dampak

\section{Pendahuluan}

Corona Virus atau biasa disebut dengan Covid-19 saat ini melanda dunia, merupakan virus yang menyebabkan penyakit pada manusia dan hewan. Saat virus ini menyerang manusia akan menyebabkan penyakit infeksi saluran pernafasan, mulai dai flu hingga Middle East Middle East Respiratory Syndrome (MERS) dan Sindrom Pernafasan Akut Berat/ Severe Acute Respiratory Syndrome (SARS), hingga saat ini ada 213 negara yang terjangkit virus corona covid 19, (https://infeksiemerging.kemkes.go.id/). Negara pertama yang terjangkit virus ini adala Cina tepatnya di kota Wuhan dan menyebar ke seluruh dunia tidak terkecuali dengan Indonesia, adanya virus ini berdampak pada semua sektor di Indonesia tidak terkecuali dengan sektor pendidikan (Pakpahan \& Fitriani, 2020). Agar sekolah dan perguruan tinggi tidak menjadi tempat strategis penyebaran Co-Vid 19 maka diberlakukan secara online, hal ini didukung dengan Menteri Pendidikan dan kebudayaan yang mengkoordinasikan pembelajaran melalui sistem daring atau online dengan mendapatkan bantuan gratis dari Ruangguru, Zenius, Google, Microsoft, Quipper, Sekolahmu, dan Kelas Pintar . Agar sektor pendidikan tetap berjalan dengan sebagaimana mestinya dan mendukung pemerintah untuk melakukan Physical Distancing maka sesuai instruksi presiden untuk tetap bekerja di rumah, belajar dirumah dan ibadah di rumah maka Menteri Pendidikan dan Kebudayaan mengeluarkan kebijakan melalui Surat Edaran (SE) No. 4 Tahun 2020 Tentang Pelaksanaan Kebijakan Pendidikan Dalam masa Darurat Penyebaran Co-Vid 19.

Kota Malang yang disebut juga dengan Kota Pendidikan merupakan salah satu kota yang disasar oleh pejuang ilmu, tiap tahunnya lebih dari 100 ribu mahasiswa baru yang mendaftar dan masuk ke berbagai perguruan tinggi negeri maupun swasta yang tersebar di Kota Malang (Helmy, 2020). Lonjakan pemudik hingga kedatangan mahasiswa baru yang lebih dari $100 \mathrm{ribu}$ orang menjadi perhatian khusus bagi Pemerintah Kota Malang, untuk mengantisipasi hal ini 
pemkot Malang melakukan koordinasi dengan rektor di seluruh perguruan tinggi tentang mekanisme penerimaan mahasiswa baru sehingga mahasiswa yang diterima di perguruan tinggi Kota Malang dapat melakukan pendaftaran ulang dan administrasi di kotanya sendiri. Dampak keputusan ini bukan hanya dirasakan oleh tenaga pendidik dan mahasiswa saja tetapi dampak ini juga dirasakan oleh beberapa pedagang makanan, toko kelontong dan pemilik kos daerah universitas. Artikel ini bertujuan untuk mengetahui keadaan perkuliahan secara online dan bagaimana dampaknya kepada mahasiswa di Kota Malang.

\subsection{Corona Virus}

Coronavirus adalah sekelompok virus yang menyebabkan penyakit pada mamalia dan burung sedangkan pada ada manusia, virus ini menyebabkan infeksi saluran pernapasan mulai dari flu (di antara kemungkinan penyebab lainnya, terutama rhinovirus), hingga SARS, MERS, dan COVID-19 (Gao et al., 2020). Pada hewan ayam virus ini menyebabkan penyakit saluran pernapasan bagian atas sedangkan pada hewan sapi dan babi akan menyebabkan diare. Vaksin dan antivirus untuk mengobati infeksi ini belum ada, orang berumur yang mempunyai masalah medis seperti kardiovaskular, diabetes, penyakit pernapasan kronis dan kanker akan lebih mudah menjadi penyakit yang lebih serius. Cara yang paling baik untuk mencegah penularan adalah dengan mengetahui penyebab penyakit ini dan pola penyebarannya, virus COVID-19 menyebar terutama melalui tetesan air liur atau cairan dari hidung saat orang yang terinfeksi batuk atau bersin (Wajdi et al., 2020). Untuk mengurangi resiko penularan ini pemerintah Cina memberlakukan lockdown tetapi tidak dengan Indonesia, pemerintah Indonesia tidak melakukan lockdown dalam skala Negara. Pada awalnya lockdown diberlakukan hanya beberapa wilayah tetapi pada bulan April 2020 hampir semua kota dan kabupaten di Indonesia memberlakukan lockdown di daerahnya yang dikenal dengan Pembatasan Sosial Berskala Besar (PSBB) yaitu kekarantinaan kesehatan yang didefinisikan sebagai pembatasan kegiatan penduduk berkelompok dalam suatu wilayah yang diduga terinfeksi penyakit atau terkontaminasi untuk mencegah penyebaran penyakit (Yunus \& Rezki, 2020). Saat ini, belum ada vaksin atau perawatan khusus untuk Covid-19 tetapi ada beberapa uji klinis yang berlangsung untuk mengevaluasi pengobatan potensial, saat ini World Health Organization (WHO) akan terus memberikan informasi terbaru saat temuan klinis sudah tersedia.

\subsection{Pendidikan}

Pendidikan adalah usaha sadar dan terencana untuk mewujudkan suasana belajar dan proses pembelajaran peserta didik aktif mengembangkan potensi dirinya untuk memiliki kekuatan spiritual keagamaan, pengendalian diri, berkepribadian, memiliki kecerdasan, berakhlak mulia, serta memiliki keterampilan yang diperlukan sebagai anggota masyarakat dan warga negara. (Undang- Undang No 20 Tahun 2003, 2003). Pendidikan nasional bertujuan mengembangkan manusia Indonesia sesuai dengan falsafah Pancasila, menjadi pribadi yang beriman dan bertaqwa terhadap Tuhan Yang Maha Esa, berakhlak mulia menguasai ilmu pengetahuan, teknologi dan seni, memiliki kesehatan jasmani dan rohani, memiliki keterampilan hidup yang berharkat dan bermartabat, memiliki jiwa yang mantap dan mandiri serta memiliki tanggung jawab kemasyarakatan dan rasa kebanggaan agar mampu mewujudkan kehidupan bangsa yang cerdas. Tujuan pendidikan nasional ini diupayakan dicapai melalui usaha dari semua pihak secara sinergis baik yang berkepentingan atau mereka yang berkepentingan atau mereka yang bertanggung jawab atas terselenggaranya pendidikan nasional. Untuk mencapai tujuan pendidikan yang mulia ini disusunlah kurikulum yang 
merupakan seperangkat rencana dan pengaturan mengenai tujuan, isi, dan bahan dan metode pembelajaran (Rusli \& Kholik, 2013).

\subsubsection{Angka Partisipasi Kasar (APK)}

Proporsi Anak sekolah pada suatu jenjang tertentu dalam kelompok usia yang sesuai dengan jenjang pendidikan tersebut. Kegunaan APK untuk menunjukkan tingkat partisipasi sekolah, tanpa memperhatikan ketepatan usia sekolah pada jenjang pendidikannya. Jika nilai APK mendekati atau lebih dari 100 persen menunjukkan bahwa ada penduduk yang sekolah belum mencukupi umur atau melebihi umur yang seharusnya. Hal ini juga dapat menunjukkan bahwa wilayah tersebut mampu menampung penduduk usia sekolah melebihi target yang sesungguhnya (MALANG, 2020).

\subsubsection{Angka Partisipasi Murni(APM)}

Proporsi anak sekolah pada suatu kelompok usia tertentu yang bersekolah pada jenjang yang sesuai dengan kelompok usianya. Kegunaan AP untuk mengukur daya serap sistem pendidikan terhadap penduduk usia sekolah. APM menunjukkan seberapa banyak penduduk usia sekolah yang sudah dapat memanfaatkan fasilitas pendidikan sesuai pada jenjang pendidikannya. Jika APM=100 berarti seluruh anak usia sekolah dapat bersekolah tepat waktu (MALANG, 2020).

\subsubsection{Angka Melek Huruf (AMH) dan Angka Buta Huruf (ABH)}

AMH merupakan proporsi penduduk usia 15 tahun ke atas yang mempunyai kemampuan membaca dan menulis huruf latin dan huruf lainnya, tanpa harus mengerti apa yang di baca/ditulisnya terhadap penduduk usia 15 tahun ke atas. Sedangkan ABH merupakan proporsi penduduk usia 15 tahun ke atas yang tidak mempunyai kemampuan membaca dan menulis huruf latin dan huruf lainnya terhadap penduduk usia 15 tahun ke atas. Kegunaan dari AMH dan ABH adalah untuk melihat pencapaian indikator dasar yang telah dicapai oleh suatu daerah, karena membaca merupakan dasar utama dalam memperluas ilmu pengetahuan. AMH merupakan indikator penting untuk melihat sejauh mana penduduk suatu daerah terbuka terhadap pengetahuan. Tingkat melek huruf yang tinggi (atau tingkat buta huruf rendah) menunjukkan adanya sebuah sistem pendidikan dasar yang efektif dan/atau program keaksaraan yang memungkinkan sebagian besar penduduk untuk memperoleh kemampuan menggunakan kata-kata tertulis dalam kehidupan sehari-hari dan melanjutkan pembelajarannya.

\subsection{Pembelajaran Online}

Menurut Dabbagh dan Ritland (dalam Arnesi dan Hamid, 2015) pembelajaran online adalah sistem belajar yang terbuka dan tersebar dengan menggunakan perangkat pedagogi (alat bantu pendidikan), yang dimungkinkan melalui internet dan teknologi berbasis jaringan untuk memfasilitasi pembentukan proses belajar dan pengetahuan melalui aksi dan interaksi yang berarti. Indonesia juga membuat kebijakan meliburkan lembaga pendidikan yang beraktifitas secara offline, akan tetapi seluruh perguruan tinggi harus menerapkan metode pembelajaran via online. Hal ini dilakukan untuk mencegah penularan Covid-19, ini bukan suatu masalah untuk perguruan tinggi yang memiliki sistem berbasis daring tetapi ini akan menjadi masalah bagi perguruan tinggi yang belum memiliki akademik berbasis daring. 
Perkuliahan dengan sistem online bertujuan memberikan kesempatan seluruh warga negara Indonesia untuk menikmati proses pembelajaran dimana saja tanpa harus datang ke universitas (Watnaya et al., 2020).

\section{Metode}

Penelitian dilakukan di Kota Malang, pemilihan Kota Malang karena kota ini adalah kota pelajar dimana 100 ribu mahasiswa tiap tahunnya mendaftar dan masuk ke berbagai perguruan tinggi negeri maupun swasta yang tersebar di Kota Malang. Penelitian ini menggunakan pendekatan eksploratif yang dimaksudkan agar bisa menggali lebih dalam dari objek yang diteliti, menjadikan topik baru lebih dikenal oleh masyarakat luas, memberikan gambaran dasar mengenai topik bahasan, menggeneralisasi gagasan dan mengembangkan teori yang bersifat tentatif, membuka kemungkinan akan diadakannya penelitian lanjutan terhadap topik yang dibahas (Sugiono, 2006). Metode analisis yang digunakan dalam penelitian ini adalah analisis data deskriptif. Metode pengambilan sampel menggunakan sampling purposive dimana teknik penentuan sampel dengan pertimbangan tertentu. Pemilihan sekelompok subjek dalam purposive sampling, didasarkan atas ciri-ciri tertentu yang dipandang mempunyai sangkut paut yang erat dengan ciri-ciri populasi yang sudah diketahui sebelumnya (Sugiono, 2006). Teknik pengumpulan data dalam penelitian ini menggunakan beberapa cara yaitu:

\subsection{Metode Observasi}

Dalam hal ini peneliti melihat serta mempelajari permasalahan yang ada dilapangan yang erat kaitannya dengan objek yang diteliti yaitu tentang dampak yang disebabkan pandemic Covid-19 pada sektor pendidikan khususnya di Kota Malang.

\subsection{Metode Studi Pustaka}

Peneliti mendapatkan sumber data dari berbagai sumber dengan cara mengumpulkan referensi yang menunjang melalui buku, jurnal, majalah dan sumber lainnya yang mendukung penelitian, metode ini digunakan dalam pengumpulan data yang berkaitan dengan dampak yang terjadi karena pandemic Covid-19 pada sektor pendidikan.

\subsection{Metode Wawancara (Interview)}

Metode wawancara adalah metode pengumpulan data, dimana peneliti melakukan secara langsung wawancara terkait dengan mahasiswa-mahasiswi Universitas di Kota Malang.

\subsection{Metode Angket (Kuisioner)}

Kuesioner merupakan teknik pengumpulan data yang dilakukan dengan cara memberi seperangkat pernyataan tertulis kepada responden untuk di jawabnya. Kuesioner yang digunakan oleh peneliti sebagai instrumen penelitian, metode yang digunakan adalah dengan kuesioner tertutup. Instrumen yang valid berarti instrument tersebut dapat dipergunakan untuk mengukur apa yang seharusnya diukur, sedangkan instrument yang reliable adalah instrumen yang apabila digunakan beberapa kali untuk mengukur objek yang sama akan menghasilkan data yang sama pula. 
Penelitian ini dilakukan pada bulan Agustus pada tahun 2020 dengan menggunakan 101 orang mahasiswa sebagai narasumber

\section{Hasil dan Pembahasan}

\subsection{Karakteristik Daerah Penelitian}

Kota Malang merupakan salah satu kota tujuan wisata di Jawa Timur karena potensi alam dan iklim yang dimiliki. Letaknya yang berada di tengah-tengah wilayah Kabupaten Malang, secara astronomis terletak pada posisi 112.06 - 112.07॰ Bujur Timur, 7.06 - 8.02。 Lintang Selatan. Batas wilayah Kota Malang sebelah utara berbatasan dengan Kecamatan Singosari dan Kecamatan Karangploso Kabupaten Malang, sebelah timur berbatasan dengan Kecamatan Pakis dan Kecamatan Tumpang Kabupaten Malang, sebelah selatan Kecamatan Tajinan dan Kecamatan Pakisaji Kabupaten Malang, sebelah barat berbatasan dengan Kecamatan Wagir dan Kecamatan Dau Kabupaten Malang. Luas wilayah Kota Malang sebesar 110,06 km² yang terbagi dalam lima kecamatan yaitu Kecamatan Kedungkandang, Sukun, Klojen, Blimbing dan Lowokwaru. Kota Malang bukan hanya merupakan kota wisata tetapi kota ini juga disebut dengan kota pendidikan karena banyak pelajar yang berbondongbondong untuk menempuh pendidikan di kota ini.

Tabel 1. Jumlah Fasilitas Pendidikan di Kota Malang Menurut Kelurahan

\begin{tabular}{|c|c|c|c|c|c|c|c|c|c|c|}
\hline \multirow{2}{*}{$\begin{array}{l}\text { Kecamatan di } \\
\text { Kota Malang }\end{array}$} & \multicolumn{10}{|c|}{ Jumlah Kelurahan yang Memiliki Fasilitas Pendidikan } \\
\hline & TK & RA & SD & MI & SMP & Mts & SMA & SMK & MA & PT \\
\hline Kedungkandang & 72 & 36 & 56 & 23 & 17 & 15 & 7 & 10 & 6 & 4 \\
\hline Sukun & 73 & 19 & 61 & 14 & 19 & 3 & 6 & 12 & 2 & 5 \\
\hline Klojen & 68 & 4 & 44 & 6 & 27 & 5 & 19 & 11 & 5 & 8 \\
\hline Blimbing & 69 & 17 & 59 & 6 & 20 & 3 & 5 & 12 & 1 & 5 \\
\hline Lowokwaru & 82 & 27 & 62 & 7 & 24 & 8 & 13 & 13 & 5 & 11 \\
\hline KOTA MALANG & 364 & 103 & 282 & 56 & 107 & 34 & 50 & 58 & 19 & 33 \\
\hline
\end{tabular}

Tabel 2. Jumlah Guru di Kota Malang Menurut Kelurahan

\begin{tabular}{lccccccccc}
\hline \multicolumn{1}{c}{\begin{tabular}{c} 
Kecamatan di \\
\multicolumn{1}{c}{ Kota Malang }
\end{tabular}} & TK & RA & SD & MI & SMP & Mts & SMA & SMK & MA \\
\hline Kedungkandang & 307 & 156 & 757 & 270 & 345 & 176 & 151 & 332 & 44 \\
Sukun & 308 & 78 & 853 & 184 & 326 & 43 & 71 & 317 & 36 \\
Klojen & 281 & 32 & 704 & 136 & 655 & 151 & 580 & 333 & 130 \\
Blimbing & 291 & 115 & 855 & 72 & 401 & 41 & 39 & 297 & 2 \\
Lowokwaru & 321 & 119 & 915 & 70 & 509 & 126 & 366 & 426 & 118 \\
KOTA MALANG & 1508 & 500 & 4084 & 732 & 2236 & 537 & 1207 & 1705 & 330 \\
\hline
\end{tabular}

Sumber: Kota Malang dalam angka 2020 (diolah)

Dengan memadainya jumlah tenaga pendidik dan fasilitas pendidikan di kota malang menyebabkan beberapa indikator seperti Angka Partisipasi Murni (APM), Angka Partisipasi Kasar (APK), Angka Partisipasi Sekolah (APS) mendekati sempurna dan angka buta huruf yang semakin berkurang. Nilai rerata APM Kota Malang 82.39 untuk SD, SMP dan SMA, nilai APM menunjukkan seberapa banyak penduduk usia sekolah yang sudah dapat memanfaatkan fasilitas pendidikan sesuai pada jenjang pendidikannya. Jika nilai IPM=100 maka seluruh anak usia sekolah dapat bersekolah tepat waktu. Rerata nilai APK Kota Malang 98.50, APK digunakan untuk menunjukkan tingkat partisipasi sekolah tanpa memperhatikan ketepatan 
usia sekolah pada jenjang pendidikannya. Jika nilai APK mendekati atau lebih dari $100 \%$ menunjukkan bahwa ada penduduk yang belum mencukupi umur atau melebihi umur yang seharusnya, hal ini juga menunjukkan bahwa wilayah Kota Malang mampu menampung penduduk usia sekolah melebihi target yang sesungguhnya. Angka melek huruf dan buta huruf digunakan untuk melihat pencapaian indikator dasar yang telah dicapai oleh suatu daerah, karena membaca merupakan dasar utama dalam memperluas ilmu pengetahuan. Kota Malang memiliki $98.17 \%$ angka melek huruf pada tahun 2019, tingkat melek huruf yang tinggi (atau tingkat buta huruf rendah) menunjukkan adanya sebuah sistem pendidikan dasar yang efektif.

Tabel 3. persentase Angka Melek huruf dan Buta Huruf di Kota Malang

\begin{tabular}{|c|c|c|c|c|c|}
\hline \multirow[t]{2}{*}{$\begin{array}{l}\text { Melek dan Buta } \\
\text { Huruf }\end{array}$} & \multicolumn{5}{|c|}{$\begin{array}{l}\text { Persentase Penduduk Usia } 15 \text { Tahun ke Atas } \\
\text { yang Melek Huruf dan Buta Huruf di Kota } \\
\text { Malang (Persen) }\end{array}$} \\
\hline & 2015 & 2016 & 2017 & 2018 & 2019 \\
\hline Melek Huruf & 98.16 & 98.17 & 97.79 & 98.43 & 98.17 \\
\hline Buta Huruf & 1.84 & 1.83 & 2.21 & 1.57 & 1.83 \\
\hline Total & 100 & 100 & 100 & 100 & 100 \\
\hline
\end{tabular}

\subsection{Kondisi Kuliah secara online}

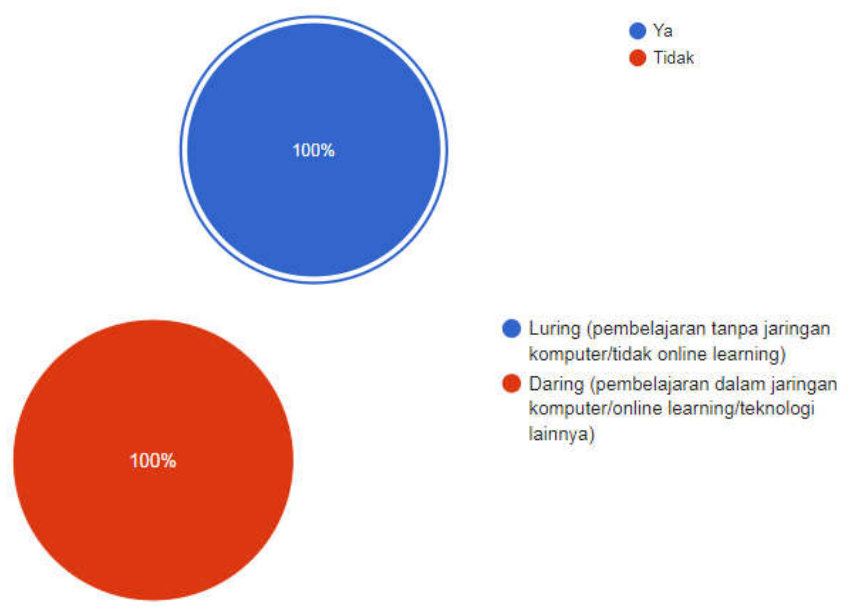

Dabbagh dan Ritland mengatakan bahwa pembelajaran online adalah sistem belajar yang terbuka dengan menggunakan alat bantu pendidikan yang melalui internet dan teknologi berbasis jaringan untuk memfasilitasi pembentukan proses belajar dan pengetahuan. Dengan diberlakukannya Surat Edaran (SE) No. 4 Tahun 2020 Tentang Pelaksanaan Kebijakan Pendidikan Dalam masa Darurat Penyebaran Covid-19 maka seluruh lini pendidikan melakukan pembelajaran secara online mulai dari tingkat Sekolah Dasar (SD) hingga tingkat universitas. Mahasiswa yang menjadi responden semuanya mengaku melakukan pembelajaran di rumah secara online, pembelajaran ini dilakukan secara daring yaitu pembelajaran dalam jaringan komputer/online learning/ menggunakan teknologi lainnya.

Sebagian besar mahasiswa menggunakan Internet Hp dan Wifi dalam melakukan kuliah online hal ini berakibat pada pertambahan biaya untuk pembeli paket data mereka mengaku biaya yang dikeluarkan dalam sebulan mengikuti kuliah daring Rp 50.000-Rp 261.000. 

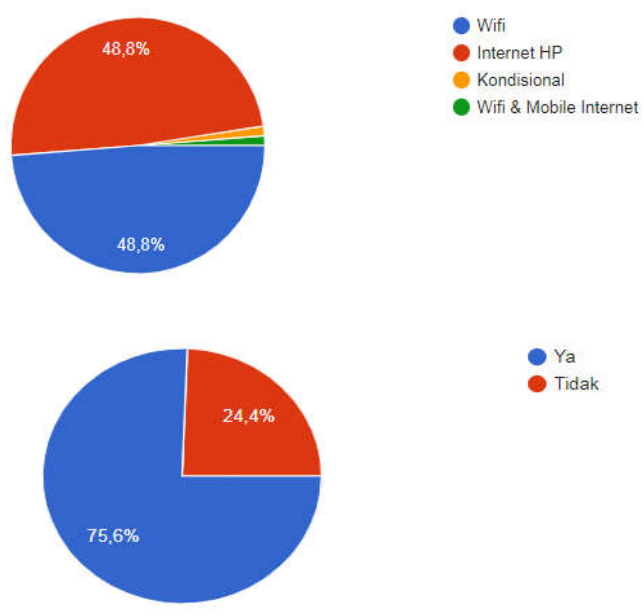

Tidak


Meskipun 75,6\% mahasiswa mengaku mendapatkan bantuan paket data dari pihak universitas dan 54,9\% mahasiswa sudah siap dengan adanya pembelajaran secara daring tetapi terdapat beberapa kendala yang menyebabkan kurang siapnya pembelajaran secara daring seperti kuota yang tidak mencukupi, internet yang tidak stabil. Dari survey yang dilakukan terdapat 57,4\% mahasiswa yang benar-benar siap dengan adanya kuliah daring hal ini didukung dengan internet yang cepat dan kuota yang cukup. Tidak semua daerah memiliki akses internet yang memadai, karena banyak mahasiswa yang kembali ke daerah asalnya dan di daerah asalnya akses internet tidak sebagus di Kota Malang maka hal ini yang menyebabkan kurang siapnya pemberlakuan kuliah online.

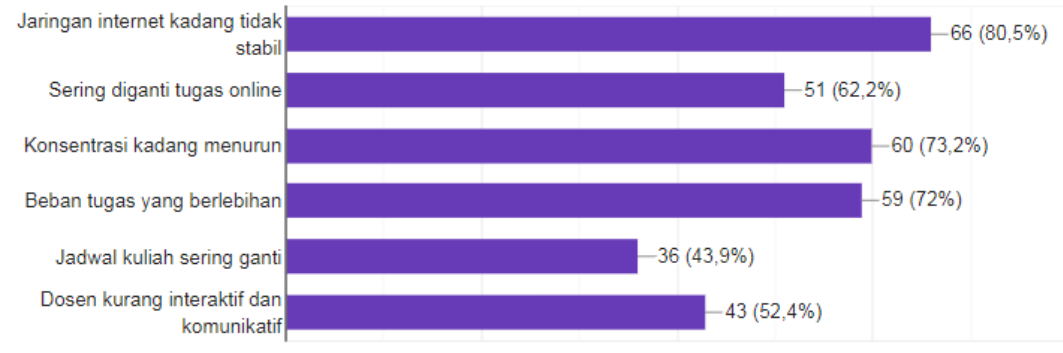

Bukan hanya internet yang kurang stabil saja yang mempengaruhi ketidak inginan untuk melakukan kuliah online ada beberapa faktor lainya seperti konsentrasi yang cepat menurun karena adanya gangguan di sekitar juga mata mudah lelah jika terlalu lama menatap layar komputer, lalu beban tugas yang diberikan juga terlalu berlebihan dan dosen kurang interaktif dan komunikatif dalam menyampaikan materi. 


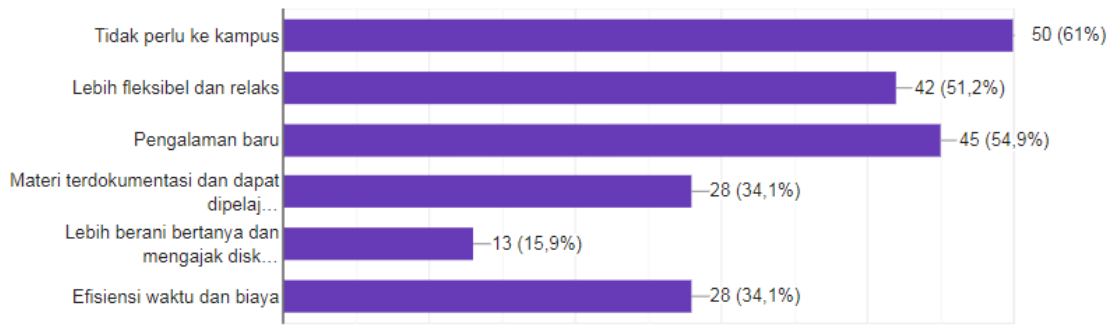

Meskipun dari 101 mahasiswa hanya 5 mahasiswa yang setuju dengan adanya kuliah online tetapi pada prakteknya kuliah online juga terdapat beberapa keuntungan seperti lebih pembelajaran lebih flexible dilakukan dimana saja sehingga mahasiswa tidak perlu ke kampus dan menghemat waktu juga biaya, dengan adanya kuliah online materi juga bisa terdokumentasi dan bisa dipelajari ulang.

\subsection{Dampak Covid-19 pada Proses Belajar Mahasiswa}

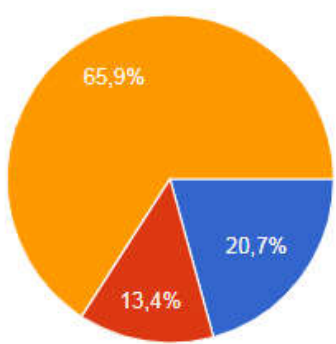

Tatap muka interaktif langsung (Webex Zoom, Skype, Webinar, dll.)

- Non-tatap muka dengan media sosial (Whatsapp, Line, Telegram, Messenger, dII.)

- Campuran (tatap muka dan non tatap muka)Campuran (tatap muka dan non tatap muka)

Pembelajaran secara daring ini menggunakan beberapa model interaksi ada yang tatap muka interaksi langsung juga non tatap muka atau hanya menggunakan media sosial seperti WhatsApp, Telegram, Messenger dan lainnya. Tidak sedikit juga dosen yang menggunakan media campuran antara tatap muka dan non tatap muka. Dengan menggunakan model interaksi yang berbeda maka penangkapan informasi juga berbeda beda. Dari 101 responden 35 diantaranya menjawab bahwa dosen mampu menerangkan $75 \%$ lebih dari materinya sedangkan 48 mahasiswa menyatakan dosen mampu memberikan kualitas penyajian materi kuliah daring melalui infografis, gambar, animasi dan video. Dengan adanya pembelajaran secara daring ini hanya 28 mahasiswa yang mampu menyerap informasi lebih dari $75 \%$ dari materi yang diterangkan oleh dosen.

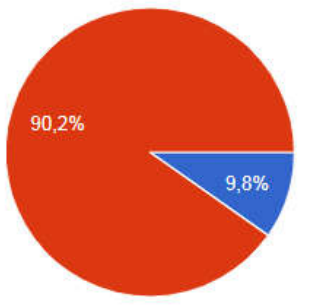




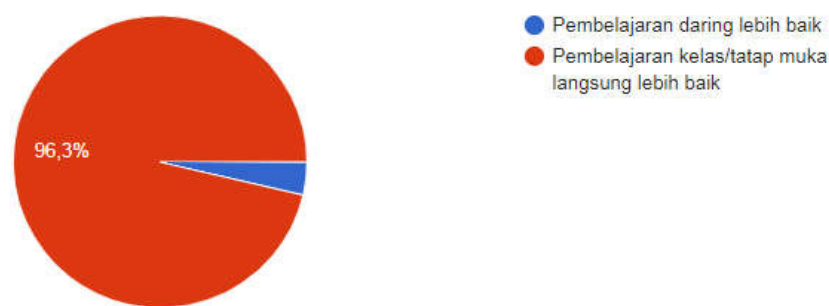

Dari survey yang dilakukan hanya 9.8\% mahasiswa yang paham dari materi yang diterangkan dan 96,3\% lebih memilih pembelajaran dikelas atau tatap muka, hal ini dikarenakan saat tatap muka materi lebih cepat tersampaikan tanpa adanya hambatan seperti internet yang tidak stabil.

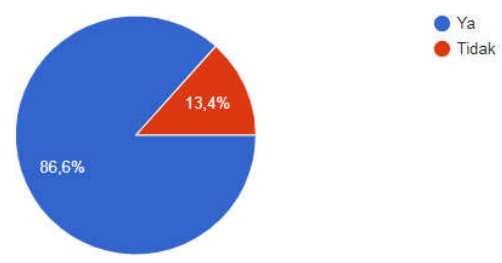

Dengan adanya kuliah online 86,6\% mahasiswa mengatakan bahwa hal ini berpengaruh terhadap Indeks Penilaian (IP) yang dicapai pada semester terkait.

\section{Simpulan}

Corona Virus atau biasa disebut dengan Covid-19 saat ini melanda dunia, merupakan virus yang menyebabkan penyakit pada manusia dan hewan. Negara pertama yang terjangkit virus ini adala Cina tepatnya di kota Wuhan dan menyebar ke seluruh dunia tidak terkecuali dengan Indonesia, adanya virus ini berdampak pada semua sektor di Indonesia tidak terkecuali dengan sektor pendidikan. Agar sektor pendidikan tetap berjalan dengan sebagaimana mestinya dan mendukung pemerintah untuk melakukan Physical Distancing maka sesuai instruksi presiden untuk tetap bekerja di rumah, belajar dirumah dan ibadah di rumah maka Menteri Pendidikan dan Kebudayaan mengeluarkan kebijakan melalui Surat Edaran (SE) No. 4 Tahun 2020 Tentang Pelaksanaan Kebijakan Pendidikan Dalam masa Darurat Penyebaran CoVid 19. Dengan diberlakukannya peraturan ini maka seluruh rektor di Indonesia memberlakukan kuliah secara daring/ online, hal ini memiliki kekurangan karena belum siapnya mahasiswa untuk menerima informasi secara daring. Belum siapnya kuliah secara online karena kurang mendukungnya akses internet dan konsentrasi yang semakin menurun juga mata lelah karena terus menerus menghadap monitor. Tetapi kuliah online juga mempunyai dampak yang baik seperti lebih flexiblenya pembelajaran karena tidak perlu dilakukan di kelas sehingga menghemat waktu dan biaya. Dari survey yang dilakukan mahasiswa lebih senang jika perkuliahan dilakukan secara offline karena materi yang disampaikan lebih mudah untuk ditangkap dan hal ini berimbas pada nilai Indeks penilaian (IP).

\section{Daftar Rujukan}

Gao, J., Tian, Z., \& Yang, X. (2020). Breakthrough: Chloroquine phosphate has shown apparent efficacy in treatment of COVID-19 associated pneumonia in clinical studies. In BioScience Trends. https://doi.org/10.5582/BST.2020.01047

MALANG, B. P. S. K. (2020). Kota Malang Dalam Angka 2020. CV. bima media mandiri. 
Jurnal Ekonomi, Bisnis dan Pendidikan, 1(3), 2021, 209-218

Pakpahan, R., \& Fitriani, Y. (2020). Analisa Pemanfaatan Teknologi Informasi dalam Pembelajaran Jarak Jauh di Tengah Pandemi Virus Corona Covid-19. Journal of Information System, Applied, Management, Accounting and Research.

Rusli, R. K., \& Kholik, M. K. (2013). Teori Belajar Dalam Psikologi Pendidikan. Jurnal Sosial Humaniora. https://doi.org/http://dx.doi.org/10.30997/jsh.v4i2.468

Sugiono, S. (2016). Metode penelitian kuantitatif, kualitatif, dan $r$ \& d. Bandung: Alfabeta

Indonesia, P. R. (2003). Undang-Undang Republik Indonesia Nomor 20 Tahun 2003 Tentang Sistem Pendidikan Nasional.

Wajdi, M. B. N., Iwan Kuswandi, Umar Al Faruq, Zulhijra, Z., Khairudin, K., \& Khoiriyah, K. (2020). Education Policy Overcome Coronavirus, A Study of Indonesians. EDUTEC : Journal of Education And Technology. https://doi.org/10.29062/edu.v3i2.42

Watnaya, a. Kusnayat, muiz, m. Hifzul, nani sumarni, M, A. Salim, \& Zaqiah, Q. Y. (2020). Pengaruh Teknologi Pembelajaran Kuliah Online Di Era Covid-19 Dan Dampaknya Terhadap Mental Mahasiswa. EduTeach : Jurnal Edukasi Dan Teknologi Pembelajaran. https://doi.org/10.37859/eduteach.v1i2.1987

Yunus, N. R., \& Rezki, A. (2020). Kebijakan Pemberlakuan Lock Down Sebagai Antisipasi Penyebaran Corona Virus Covid-19. SALAM: Jurnal Sosial Dan Budaya Syar-I. https://doi.org/10.15408/sjsbs.v7i3.15083 